\title{
Fungitoxicity of Methyl Iodide, Sulfuryl Fluoride, and Methyl Bromide to Ceratocystis fagacearum in Red Oak, Maple, Poplar, Birch and Pine Wood
}

\author{
Kayimbi M. Tubajika ${ }^{1}$, Alan V. Barak ${ }^{2}$ \\ ${ }^{1}$ United States Department of Agriculture (USDA), Animal and Plant Health Inspection Service (APHIS), Plant Protection and \\ Quarantine (PPQ), Center for Plant Health Science and Technology (CPHST), Raleigh, USA; ${ }^{2}$ United States Department of Agricul- \\ ture (USDA), Animal and Plant Health Inspection Service (APHIS), Plant Protection and Quarantine (PPQ), Center for Plant Health \\ Science and Technology (CPHST), Buzzard Bay, USA. \\ Email: kayimbi.tubajika@aphis.usda.gov,Abarak@aphis.usda.gov, afbarak@verizon.net
}

Received April 5 $5^{\text {th }}, 2011$; revised May $3^{\text {rd }}, 2011$; accepted May $15^{\text {th }}, 2011$.

\begin{abstract}
The threat of wood-inhabiting fungi to American hardwood forests, lumber industries, and tourism has enormous economic significance, and the aesthetic and dollar values of properties are potentially disastrous. The efficacy of methyl iodide (MeI) and sulfuryl fluoride (SF) for eradicating wood-inhabiting fungus, Ceratocystis fagacearum was assessed in wood blocks of birch, maple, poplar and red pine based on in-vitro experiments. In a series of replicated controlled experiments, wood blocks were inoculated with a $1 \mathrm{~g}$ macerated mycelium/spores mixture of $C$. fagacearum and fumigated with 160 and $240 \mathrm{~g} / \mathrm{m}^{3}$ of MeI, SF and methyl bromide (MeBr) as control) for 24, 48, and 72 hours. Analysis of variance showed that fumigant types, fumigant concentrations, and exposure time as well as their interactions $(C \times T)$ had an effect on C. fagacearum recovery on tested wood species. Colonization of birch, maple, red pine, and poplar by C. fagacearum was significantly greater in non-fumigated samples than fumigated samples. C. fagacearum was greatly inhibited by MeI than SF in all wood species tested. Overall, the $C \times T$ products of $\leq 4.108 \mathrm{~g} \cdot \mathrm{h} / \mathrm{m}^{3}$ for MeI and $\leq 8.755$ $\mathrm{g} \cdot \mathrm{h} / \mathrm{m}^{3}$ for SF were not effective in killing the fungus. These results suggest that longer treatment exposure time might achieve the goal of complete eradication of C. fagacearum and imply that MeI performed as well as MeBr in killing the fungus in some wood species by exposure time combination. Overall, MeI was most effective in killing the fungus than $S F$ under the conditions of this study with potential implications for quarantine use.
\end{abstract}

Keywords: Disease Control, Quarantine Treatment, Fumigation, Quercus Rubra

\section{Introduction}

The threat of wood-inhabiting fungi to American hardwood forests, lumber industries, tourism, and the aesthetic and dollar values of properties, is potentially disastrous. Biodegradation of wood is accomplished in part by insects and marine borers, but the greatest degree of deterioration and product devaluation is caused by woodinhabiting fungi [1-3]. Solid wood packing material (SWPM) is recognized as a major pathway for introduction of insects and pathogens into the United States which then subsequently infects indigenous tree (wood) species [4-6].

Currently, exported SWPM is disinfected by methyl bromide (MeBr) fumigation and conventional heat sterilization $[7,8]$. Methyl bromide has been used for nearly sixty years to control a wide range of pests and diseases in the production of high value crops such as strawberries, flowers, melons, peppers and tomatoes; foodstuffs associated with storage and certain commodities such as grain in trade to prevent the spread of pests and diseases as indicated in UNEP Kenya report [9].

Restrictions on $\mathrm{MeBr}$ use have increased interest in developing alternative treatments for SWPM [10-12]. Methyl iodide (MeI) and sulfuryl fluoride (SF) have been considered as alternatives to $\mathrm{MB}$, however; research on these fumigants has been limited to few wood-inhabiting fungi and nematodes $[7,8,13,14]$. Therefore, scientific data are required to support quarantine treatments, especially with regulations for the reduction of $\mathrm{MeBr}$ use as a quarantine treatment. The objective of this study was to determine the fungitoxicity of methyl iodide, sulfuryl fluoride and methyl bromide to Ceratocystis fagacearum 
in red oak, maple, poplar, birch and pine wood. Preliminary studies have been published $[15,16]$.

\section{Materials and Methods}

\subsection{Fumigants}

\subsubsection{Methyl Bromide}

$(\mathrm{MeBr})$ is an odorless, colorless gas that has been used as an agricultural soil and structural fumigant to control a wide variety of pests. However, because $\mathrm{MeBr}$ deplete the stratospheric ozone layer and is classified as a Class I ozone-depleting substance, the amount of $\mathrm{MeBr}$ produced and imported in The U.S. was incrementally reduced until the phase-out took effect on January 1, 2005, except for allowable exemptions. These exemptions include the Quarantine and Pre-shipment (QPS) exemptions, to eliminate quarantine pests, and the Critical Use Exemption (CUE), designed for agricultural users with no technical or economically feasible alternatives $[17,18]$.

\subsubsection{Sulfuryl Fluoride}

(SF) is used as a structural fumigant and is easy to apply. It is nonflammable and noncorrosive and it offers high diffusion for rapid penetration and aeration [19]. It has been also considered as a potential alternative to $\mathrm{MeBr}$. Similarly, research on $\mathrm{MeBr}$ as well as other fumigants has been limited to few wood inhabiting fungi and nematodes [19-21]. There is need for development of new treatments in order to support quarantine treatment.

\subsubsection{Methyl Iodide}

(MeI) degrades in sunlight with resulting low ozone depletion potential, chemically reacts as an alkylating agent and possesses a lower melting point for increased worker safety. It is reported to be a good soil fumigant and it has also been reported to kill live parenchyma cell in logs $[13,21]$. Although, MeI and SF have been considered as alternatives to $\mathrm{MeBr}$, researches on these fumigants have been limited to few wood-inhabiting fungi and nematodes [13].

\subsection{Fungi}

The fungal species commonly associated with wood degradation, Ceratocystis fagacearum was chosen for this study because of its common occurrence, economic importance and previous work on fumigation with $\mathrm{MeBr}$ and SF $[21,22]$. The fungus was grown on oak wilt medium [23] for two weeks at $27^{\circ} \mathrm{C}$ or until almost complete colonization of the plates.

\subsection{Wood Block Tests}

In a series of controlled experiments, wood blocks of birch, maple, poplar and red pine $(2.5 \times 2.5 \times 1.0 \mathrm{~cm})$ were inoculated with a $1 \mathrm{~g}$ macerated mycelium/spores mixture of $C$. fagacearum Identical wood blocks were left untreated (or non-fumigated) as controls. Wood was then incubated at $27^{\circ} \mathrm{C}$ for a minimum of 30 days. A factorial experiment [3 fumigants (methyl iodide, MeI; sulfuryl fluoride, SF; and methyl bromide, $\mathrm{MeBr}$ ); 2 fumigant concentrations $\left(160\right.$ and $\left.240 \mathrm{~g} / \mathrm{m}^{3}\right) ; 4$ wood types (birch, red pine, maple, and poplar); and 3 exposure times (24, 48, and 72 hours)] was arranged in a completely randomized design with four replications. The experiment was replicated twice.

\subsection{Fumigation}

All fumigations were conducted at room temperature $\left(21^{\circ} \mathrm{C} \pm 2^{\circ} \mathrm{C}\right)$. Fumigations were performed in sealed ca. $10.0 \mathrm{~L}$ glass fumatoria jars with $100 \%$ pure liquid MeI, 99.98 pure $\mathrm{SF}$ and $100 \%$ pure $\mathrm{MeBr}$ in separate containers at concentrations of 160 and $240 \mathrm{~g} / \mathrm{m}^{3}$. Each fumitorium was fitted with a small $12 \mathrm{~V}$ DC fan to Mix and circulate the fumigant gas. Fumigants were injected as pure neat liquid (MeI) or gases (SF) and $\mathrm{MeBr}$ with a gas-tight syringe (Hamilton, Reno, Nevada 89502) into the chambers through a 0.25 in. compression fitted with a $10 \mathrm{~mm}$ silicone septa after first withdrawing an equivalent volume of air. The liquid MeI was injected onto a piece of filter paper, from which it was allowed to evaporate. Fumigant concentrations in the test chambers and control chamber were monitored at intervals of $0.5,2$, 4, 24, 48, and 72 hours. Fumigant concentrations were monitored with a Sapphire infrared gas analyzer (Thermo-Fisher, Franklin, MA). Sample of $2.5 \mathrm{ml}$ volume were directly injected into the analyzer, which was fitted with a closed loop tube, which resulted in a sample dilution factor of 905. A custom low-ppm application was developed by this laboratory. Wood was sampled aseptically from the jars and cultured for the presence of the pathogen as described below. The time-weighted concentration $\left(\mathrm{g} / \mathrm{m}^{3}\right)$ was multiplied by the period of exposure, in hours, to obtain the concentration time $(\mathrm{C} \times \mathrm{T})$ product, which was used to express dosage. After fumigation, the glass jar lids were removed and the wood filled chambers were aired out in a fume cabinet for $24 \mathrm{hr}$. Untreated wood were aired in a separate fume cabinet. Woods were sampled aseptically from the jar and cultured for the presence of the pathogen.

\subsection{Pathogen Isolation}

The efficacy of SF or MeI in killing tested fungus was determined by attempts to isolate the pathogen from wood shavings. The effectiveness of SF and MeI in killing the fungus was compared to the standard fumigant, $\mathrm{MeBr}$. After the completion of the fumigation and sub- 
sequent incubation, samples obtained at 10 different locations on wood block surfaces were quickly transferred using flame-sterilized tweezers onto amended malt yeast agar and oak wilt medium. All isolations of suspected test fungi were sub-cultured and subsequently compared with the reference test fungi used as controls. Pathogen isolation attempts were made before and after fumigation treatments. Precautions were observed to prevent crosscontamination of samples and aseptic procedures were used.

\subsection{Data Analysis}

Experiments were analyzed separately for each fumigant and combined when treatments-by-experiments were not significantly different. The experiment was carried out in a completely randomized design with four replicates. Each wood block was considered as a replicate and the experiment was conducted twice. The graphical plots of data on percent fungal recovery versus $\mathrm{C} \times \mathrm{T}$ were done. Fungal recovery (\%) was measured by number of wood block sections with visible growth after 2 weeks of incubation/total blocks inoculated $\times 100$. Fungal recovery and $\mathrm{C} \times \mathrm{T}$ data from the fumigant treatments were subjected to the General Linear Models procedure of SAS (SAS Institute, Cary, NC). Treatment means were separated using Fisher's protected least significant difference (LSD) test at $P=0.05$.

\section{Results}

Analyses showed no significant test-by-treatments interaction for the fungal growth, therefore, data from duplicate tests were combined for final analysis. Analysis of variance indicated statistically significant differences among fumigants, fumigant concentrations and exposure time as well as their interactions effected C. fagacearum recovery on tested wood species. There was no difference in response of these fumigants on wood species (Tables 1-3). Pathogen recovery was greater at $24 \mathrm{hr}$ than at $72 \mathrm{hr}$ after fumigation (Figures 1 and 2). The percent of pathogen recovery from wood exposed to MeI and $\mathrm{SF}$ for $24 \mathrm{~h}$ ranged from $0 \%$ (red pine) to $6 \%$ (birch); $3 \%$ (poplar) to $24 \%$ (maple); and $0 \%$ (red pine, poplar) to $5 \%$ (maple), and this depended on the fumigant concentration (Tables 1 and 2, Figures 1 and 2).

Complete absence of the pathogen was achieved after birch and red pine samples were exposed to $160 \mathrm{~g} / \mathrm{m}^{3}$ concentration of MeI for $48 \mathrm{~h}$ or after birch, red pine, maple, and poplar samples were exposed to $160 \mathrm{~g} / \mathrm{m}^{3}$ of MeI for $72 \mathrm{~h}\left(\mathrm{C} \times \mathrm{T}\right.$ products of 5, 491-11, $\left.704 \mathrm{~g} \cdot \mathrm{h} / \mathrm{m}^{3}\right)$ (Table 1). In samples fumigated with SF, complete absence of the pathogen was achieved after maple samples were exposed to $160 \mathrm{~g} / \mathrm{m}^{3}$ for $72 \mathrm{~h}(\mathrm{C} \times \mathrm{T}$ product of $\left.11,316 \mathrm{~g} \cdot \mathrm{h} / \mathrm{m}^{3}\right)$. SF killed the fungus in birch, red pine, maple, and poplar samples fumigated at $240 \mathrm{~g} / \mathrm{m}^{3}$ concentration for $24 \mathrm{~h}(\mathrm{C} \times \mathrm{T}$ products of $5817-16,466$ $\mathrm{g} \cdot \mathrm{h} / \mathrm{m}^{3}$ ) (Table 2).

Methyl bromide killed C. fagacearum in red pine, maple, and poplar samples exposed at $160 \mathrm{~g} / \mathrm{m}^{3}$ for $24 \mathrm{~h}$. No survival of the pathogen was observed in all tested wood species treated with $\mathrm{MeBr}$ at $240 \mathrm{~g} / \mathrm{m}^{3}$ for $24 \mathrm{~h}(\mathrm{C} \times \mathrm{T}$ product of $9529-13,532 \mathrm{~g} \cdot \mathrm{h} / \mathrm{m}^{3}$ ) (Table 3, Figure 3). Colonization of birch, maple, red pine, and poplar by $C$. fagacearum was greater in non-fumigated samples than fumigated samples (Table 4, Figures 2 and 3). C. fagacearum was greatly inhibited by MeI than $\mathrm{SF}$ in all wood species tested (Tables 1 and 2). Overall, the $\mathrm{C} \times \mathrm{T}$ products of $\leq 4.108 \mathrm{~g} \cdot \mathrm{h} / \mathrm{m}^{3}$ for MeI and $\leq 8.755 \mathrm{~g} \cdot \mathrm{h} / \mathrm{m}^{3}$ for $\mathrm{SF}$ were not effective in killing the fungus.

Table 1. Percent Ceratocystis fagacearum recovered from cultured wood samples following fumigation with methyl iodide.

\begin{tabular}{|c|c|c|c|c|c|c|c|}
\hline \multirow{2}{*}{ Fumigant Conc. $\left(\mathrm{g} / \mathrm{m}^{3}\right)$} & \multirow{2}{*}{ Exposure time (h) } & \multirow{2}{*}{ Conc. $\times$ time $\left(\mathrm{g} \cdot \mathrm{h} \cdot \mathrm{m}^{3}\right)^{\mathrm{y}}$} & \multicolumn{5}{|c|}{ Percent pathogen recovery ${ }^{\mathrm{x}}$} \\
\hline & & & Birch & Red pine & Maple & Poplar & Mean \\
\hline 160 & 24 & 2,827 & $6.23 \pm 2.55^{z}$ & $5.32 \pm 3.02$ & $5.11 \pm 2.34$ & $5.24 \pm 1.32$ & $5.48 \pm 1.27$ \\
\hline 160 & 48 & 5,491 & $0.00 \pm 0.00$ & $0.00 \pm 0.00$ & $1.12 \pm 0.92$ & $2.06 \pm 0.98$ & $0.79 \pm 0.48$ \\
\hline 160 & 72 & 7,840 & $0.00 \pm 0.00$ & $0.00 \pm 0.00$ & $0.00 \pm 0.00$ & $0.00 \pm 0.00$ & $0.00 \pm 0.00$ \\
\hline 240 & 24 & 4,108 & $1.17 \pm 0.06$ & $0.00 \pm 0.00$ & $2.03 \pm 0.08$ & $0.00 \pm 0.00$ & $0.80 \pm 0.02$ \\
\hline 240 & 48 & 7,805 & $0.00 \pm 0.00$ & $0.00 \pm 0.00$ & $0.00 \pm 0.00$ & $0.00 \pm 0.00$ & $0.00 \pm 0.00$ \\
\hline 240 & 72 & 11,704 & $0.00 \pm 0.00$ & $0.00 \pm 0.00$ & $0.00 \pm 0.00$ & $0.00 \pm 0.00$ & $0.00 \pm 0.00$ \\
\hline Mean & & & $1.23 \pm 0.23$ & $0.89 \pm 0.16$ & $1.04 \pm 0.31$ & $1.22 \pm 0.59$ & \\
\hline
\end{tabular}

${ }^{\mathrm{x}}$ Percentage of samples removed from fumigated wood that showed $C$. fagacearum growth after transfer onto oak wilt medium. ${ }^{\mathrm{y}}$ The average concentration was multiplied by the period of exposure in hours to obtain the concentration time product $(\mathrm{C} \times \mathrm{T})$ used to express dosage. ${ }^{\mathrm{z}}$ Mean of duplicate experiments $(200$ isolations total). 
Table 2. Percent Ceratocystis fagacearum recovered from cultured wood samples following fumigation with sulfuryl fluoride.

\begin{tabular}{|c|c|c|c|c|c|c|c|}
\hline \multirow{2}{*}{$\begin{array}{l}\text { Fumigant Conc. } \\
\qquad\left(\mathrm{g} / \mathrm{m}^{3}\right)\end{array}$} & \multirow{2}{*}{$\begin{array}{c}\text { Exposure time } \\
\text { (h) }\end{array}$} & \multirow{2}{*}{$\begin{array}{l}\text { Conc. } \times \text { time } \\
\left(\mathrm{g} \cdot \mathrm{h} \cdot \mathrm{m}^{3}\right)^{\mathrm{y}}\end{array}$} & \multicolumn{5}{|c|}{ Percent pathogen recovery ${ }^{x}$} \\
\hline & & & Birch & Red pine & Maple & Poplar & Mean \\
\hline 160 & 24 & 3860 & $24.86 \pm 1.57^{\mathrm{z}}$ & $16.23 \pm 1.54$ & $24.13 \pm 1.92$ & $19.87 \pm 2.64$ & $21.22 \pm 1.90$ \\
\hline 160 & 48 & 7574 & $4.02 \pm 1.46$ & $4.12 \pm 1.92$ & $9.80 \pm 1.96$ & $6.42 \pm 2.08$ & $6.09 \pm 1.80$ \\
\hline 160 & 72 & 11316 & $0.89 \pm 0.10$ & $1.61 \pm 0.34$ & $0.00 \pm 0.00$ & $1.24 \pm 0.56$ & $0.94 \pm 0.25$ \\
\hline 240 & 24 & 5817 & $5.23 \pm 2.07$ & $4.17 \pm 2.24$ & $5.08 \pm 1.72$ & $3.02 \pm 1.26$ & $4.38 \pm 1.66$ \\
\hline 240 & 48 & 8755 & $1.06 \pm 0.84$ & $1.80 \pm 0.89$ & $2.56 \pm 0.78$ & $2.19 \pm 0.98$ & $1.90 \pm 0.85$ \\
\hline 240 & 72 & 16466 & $0.00 \pm 0.00$ & $0.00 \pm 0.00$ & $0.00 \pm 0.00$ & $0.00 \pm 0.00$ & $0.00 \pm 0.00$ \\
\hline Mean & & & $6.01 \pm 0.99$ & $4.66 \pm 1.34$ & $6.93 \pm 0.98$ & $5.46 \pm 1.22$ & \\
\hline
\end{tabular}

${ }^{\mathrm{x}}$ Percentage of samples removed from fumigated wood that showed C. fagacearum growth after transfer onto oak wilt medium. ${ }^{\mathrm{y}}$ The average concentration was multiplied by the period of exposure in hours to obtain the concentration time product $(\mathrm{C} \times \mathrm{T})$ used to express dosage. ${ }^{\mathrm{z}}$ Mean of duplicate experiments $(200$ isolations total).

Table 3. Percent Ceratocystis fagacearum recovered from cultured wood samples following fumigation with methyl bromide.

\begin{tabular}{|c|c|c|c|c|c|c|c|}
\hline \multirow{2}{*}{$\begin{array}{l}\text { Fumigant Conc. } \\
\qquad\left(\mathrm{g} / \mathrm{m}^{3}\right)\end{array}$} & \multirow{2}{*}{$\begin{array}{l}\text { Exposure time } \\
\text { (h) }\end{array}$} & \multirow{2}{*}{$\begin{array}{l}\text { Conc. } \times \text { time } \\
\left(\text { g.h. } \mathrm{m}^{3}\right)^{\mathrm{y}}\end{array}$} & \multicolumn{5}{|c|}{ Percent pathogen recovery ${ }^{\mathrm{x}}$} \\
\hline & & & Birch & Red pine & Maple & Poplar & Mean \\
\hline 160 & 24 & 3363 & $2.46 \pm 1.05^{z}$ & $3.92 \pm 1.32$ & $5.08 \pm 1.43$ & $3.62 \pm 1.19$ & $3.78 \pm 1.22$ \\
\hline 160 & 48 & 6174 & $1.12 \pm 0.00$ & $0.00 \pm 0.00$ & $2.98 \pm 0.16$ & $1.13 \pm 0.38$ & $1.31 \pm 0.06$ \\
\hline 240 & 24 & 4873 & $1.32 \pm 0.11$ & $0.00 \pm 0.00$ & $0.00 \pm 0.00$ & $0.00 \pm 0.00$ & $0.33 \pm 0.01$ \\
\hline 240 & 48 & 9529 & $0.00 \pm 0.00$ & $0.00 \pm 0.00$ & $0.00 \pm 0.00$ & $0.00 \pm 0.00$ & $0.00 \pm 0.00$ \\
\hline 240 & 72 & 13,532 & $0.00 \pm 0.00$ & $0.00 \pm 0.00$ & $0.00 \pm 0.00$ & $0.00 \pm 0.00$ & $0.00 \pm 0.00$ \\
\hline Mean & & & $0.82 \pm 0.14$ & $0.66 \pm 0.18$ & $1.48 \pm 0.24$ & $0.77 \pm 0.23$ & $0.00 \pm 0.00$ \\
\hline
\end{tabular}

${ }^{\mathrm{x}}$ Percentage of samples removed from fumigated wood that showed $C$. fagacearum growth after transfer onto amended malt yeast agar and oak wilt medium. ${ }^{\mathrm{y}}$ The average concentration was multiplied by the period of exposure in hours to obtain the concentration time product $(\mathrm{C} \times \mathrm{T})$ used to express dosage. ${ }^{\mathrm{z}}$ Mean of duplicate experiments (200 isolations total).

Table 4. Percent Ceratocystis fagacearum recovered from cultured wood samples non-fumigated with sulfuryl fluoride and methyl iodide.

\begin{tabular}{|c|c|c|c|c|c|}
\hline \multirow{2}{*}{ Exposure time (h) } & \multicolumn{5}{|c|}{ Percent pathogen recovery ${ }^{\mathrm{y}}$} \\
\hline & Birch & Red pine & Maple & Poplar & Mean \\
\hline 24 & $84.26 \pm 3.57^{z}$ & $98.84 \pm 2.13$ & $94.66 \pm 3.07$ & $96.73 \pm 1.51$ & $93.62 \pm 2.22$ \\
\hline 48 & $98.24 \pm 1.86$ & $98.38 \pm 2.52$ & $96.01 \pm 1.386$ & $97.18 \pm 2.12$ & $97.45 \pm 1.73$ \\
\hline Mean & $93.43 \pm 2.36$ & $98.75 \pm 2.12$ & $96.05 \pm 2.15$ & $97.57 \pm 2.04$ & \\
\hline
\end{tabular}

${ }^{\mathrm{y}}$ Percentage of samples removed from nonfumigated wood that showed fungal growth after transfer onto oak wilt medium. ${ }^{\mathrm{z}}$ Mean of duplicate experiments $(100$ isolations total).

The results from this study suggest that longer treatment time might achieve the goal of complete eradication of C. fagacearum and imply that MeI performed as well as $\mathrm{MeBr}$ in killing the fungus in some wood species by 


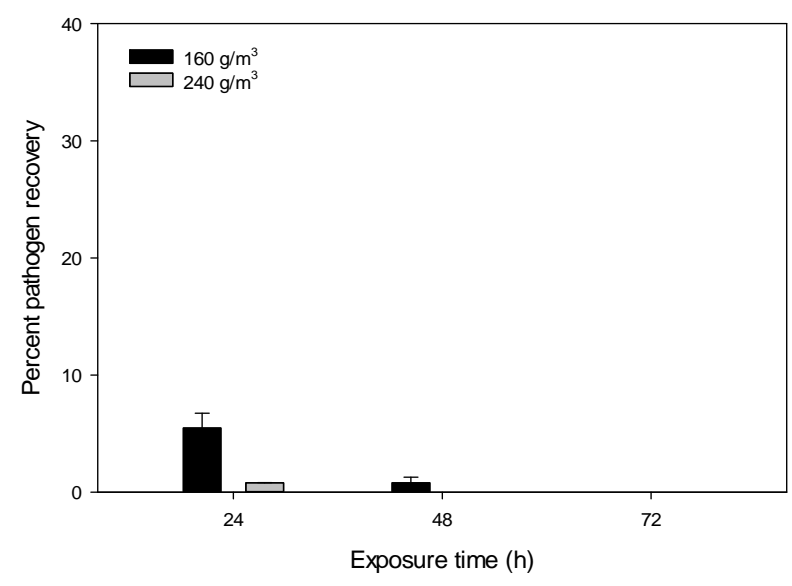

(a)

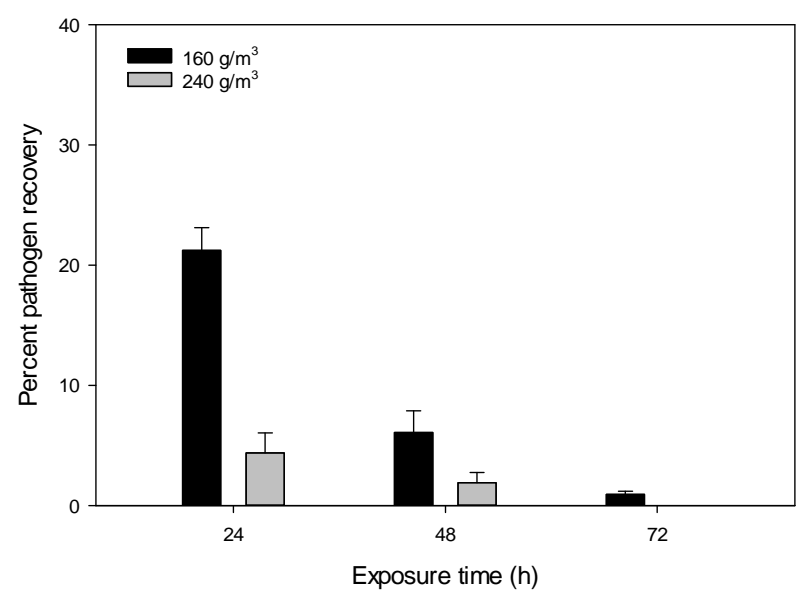

(b)

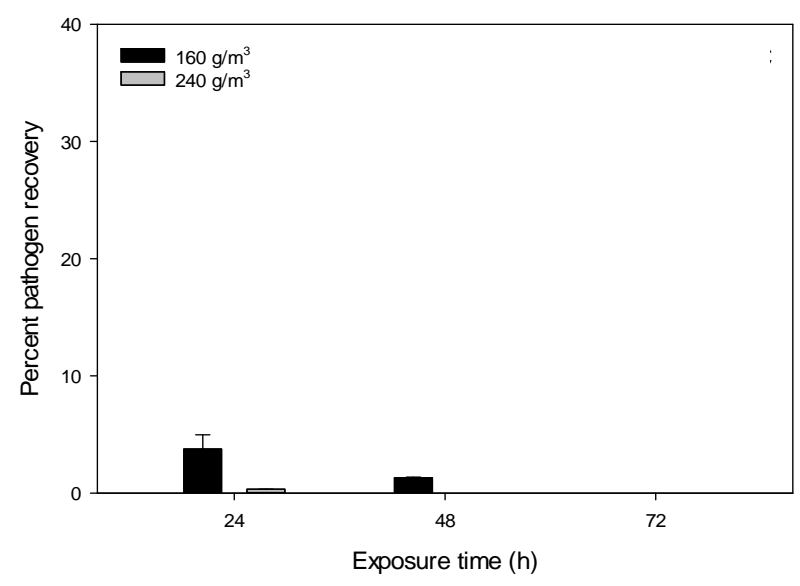

(c)

Figure 1. Percent pathogen recovery from cultured birch, red pine, maple, and poplar samples fumigated with 160 $\mathrm{g} / \mathrm{m}^{3}$ and $240 \mathrm{~g} / \mathrm{m}^{3}$ of methyl iodide (a), sulfuryl fluoride (b), and methyl bromide (c). Data are averaged across wood species. exposure time combination. Overall, MeI was most effective in killing the fungus than SF under the conditions of this study.

\section{Discussion}

The isolation of fungus from wood samples previously inoculated and colonized by $C$. fugacearum and the absence in uninoculated controls as well as wood samples fumigated at concentrations as high as 80 and $96 \mathrm{~g} / \mathrm{m}^{3}$ indicates that these fumigants may be effective against quarantined pest of SWPM.

This finding indicates that the efficacy of the MeI, $\mathrm{MeBr}$ and SF fumigation may depend on the level of wood colonization of the tested fungi and the technique used to detect the pathogen in wood.

Methyl bromide and sulfuryl fluoride did not have an effect on C. fimbriata and C. polonica in red oak and poplar samples at $\mathrm{C} \times \mathrm{T}$ products as high as $2000 \mathrm{~g} \cdot \mathrm{h} / \mathrm{m}^{3}$ under the conditions of this study (Data not shown). The $\mathrm{C} \times \mathrm{T}$ products used to effectively kill $C$. fagacearum in this study are, however, less than previously reported for C. fagacearum [22,24-27] but higher than those recommended by the USDA [28]. Jones [24] reported a-100\% mortality of $C$. fagacearum with a $\mathrm{C} \times \mathrm{T}$ of 45,000 mgh/L MB. Patridge [26] and Schmidt [26]; Schmidt et al. [27] also reported a-100\% mortality of $C$. fagacearum at a $\mathrm{C} \times \mathrm{T}$ of $45,000 \mathrm{mgh} / \mathrm{L}$. Rhatigan et al. [29] reported survival of 8 and $12 \%$ of $H$. annosum and L. wageneri at $\mathrm{C} \times \mathrm{T}$ values high as 3010 and $4750 \mathrm{mgh} / \mathrm{L}$ of $\mathrm{MeBr}$, respectively, in Larch heartwood. They estimated a complete eradication of $H$. annosum and $L$. wageneri at $\mathrm{C} \times \mathrm{T}$ values less than 4000 and $6000 \mathrm{mgh} / \mathrm{L}$ of $\mathrm{MeBr}$, respectively. MacDonald et al. (1985) reported that fumigation with $\mathrm{MB}$ at $240 \mathrm{~g} / \mathrm{m}^{3}$ for $72 \mathrm{~h}$ eradicated C. fagacearum from red oak logs.

Overall, C. fagacearum was resistant to $\mathrm{MeBr}$ or $\mathrm{SF}$ in the conditions of this study. It is not known however, if fumigation of natural wood products naturally infected with the plant pathogens would result in fungal mortality or inhibition. In a study on fungitoxicity of sulfuryl fluoride to $C$. fagacearum in vitro and in wilted red oak log sections, Woodward and Schmidt reported 15 and 7\% reduction in $C$. fagacearum isolation at concentrations as high as 160 or $220 \mathrm{~g} / \mathrm{m}^{3}$ of SF for $72 \mathrm{~h}$, in red oak log sections, respectively. No C. fagacearum growth was noted from $\log$ sections fumigated with $280 \mathrm{~g} / \mathrm{m}^{3}$ for $72 \mathrm{~h}$ $(\mathrm{C} \times \mathrm{T}$ of 18,530). Woodward and Schmidt [19] laboratory's finding on eradication of C. fagacearum with SF were in contrast with field data obtained by Schmidt et al. [30] showing the presence of the fungus after MeBr fumigation. They suggested longer treatment time to in crease the chance of obtaining complete eradication of 


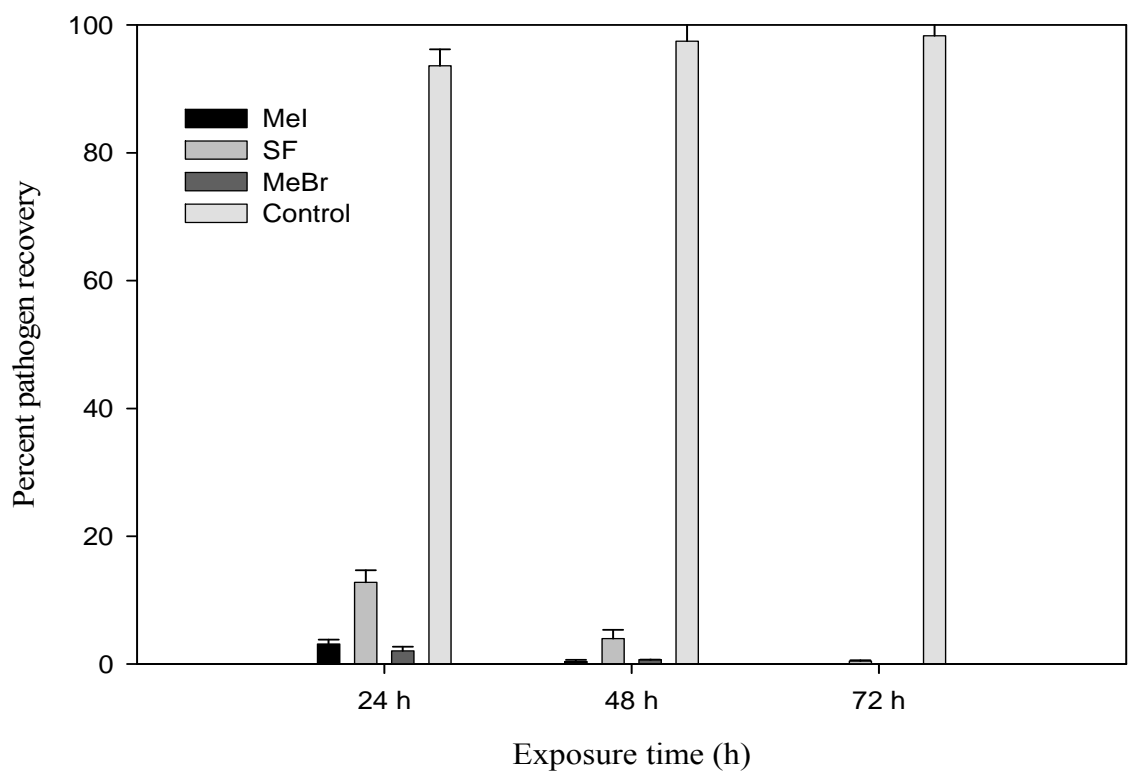

Figure 2. Percent pathogen recovery from cultured birch, red pine, maple, and poplar nonfumigated and fumigated samples with methyl iodide, sulfuryl fluoride, and methyl bromide. Data are averaged across wood species.

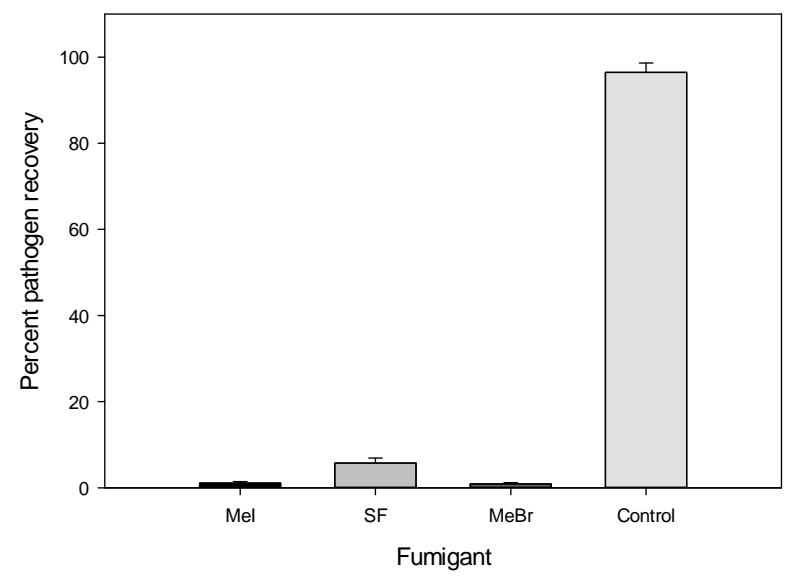

Figure 3. Percent Ceratocystis fagacearum recovery from cultured birch, red pine, maple and poplar samples following fumigation with methyl iodide, sulfuryl fluoride, methyl bromide, and nonfumigated controls. Data are averaged across wood species, exposure time and fumigant concentrations.

the fungus in the logs. This suggests that the differences in SF treatment effects may have been accounted for by moisture or other treatment conditions of the two experiments.

The ineffectiveness of $\mathrm{MeBr}$ or SF to kill $C$. fagacearum in red oak and poplar samples may possibly due to their deep penetration into wood, to exposure time used in this study, wood characteristics, sorption, or to other unknown factors. It is probable that SF at concentrations less than $240 \mathrm{~g} / \mathrm{m}^{3}$ is not sufficient to deplete energy lev- els of fungal cells to delay hyphal elongation and/ or to disrupt cell metabolism as observed in SF-insect systems reported elsewhere [31,32]. Kawakami et al. [13] suggested that when bulk wood of lower moisture content (which is more sorbent of MeBr) is fumigated, such fumigation will require higher doses than indicated here to achieve the requisite $\mathrm{C} \times \mathrm{T}$ product.

This study documents on the effect of MeI, SF and $\mathrm{MeBr}$ fumigation on a number of wood-inhibiting fungi. We have demonstrated that a concentration of $240 \mathrm{~g} / \mathrm{m}^{3}$ $\mathrm{MeBr}$ or SF (highest concentration used in this study) is not effective or adequate to control all wood fungi tested. This study together with previous studies by Rhatigan et al. [29,32-34] showed clearly that the $\mathrm{MeBr}$ fumigation is not effective in killing $C$. fagacearum as tested in this study. Additional studies are aimed at determining the penetration of MeI and SF fumigants throughout logs at different concentrations and temperatures in different wood species and fungi combinations.

\section{Acknowledgements}

We are indebted to Jami L. Nydam (USDA CPHST Otis Pest survey, Detection and Exclusion laboratory, MA) for laboratory assistance, to Drs Tom Harrington of Iowa State University and Jodi Jellison of University of Maine for the culture used in this study, and two anonymous reviewers for helpful comments.

\section{REFERENCES}

[1] R. L. Schmidt, D. L. Cassens and B. A. Jordan, "Control 
of Graystain in Yellow-Poplar Lumber by Log Fumigation with Sulfuryl Fluoride," Forest Products Journal, Vol. 51, No. 9, 2001, pp. 50-52.

[2] J. W. Dubois and J. N. Ruddick, "The Fungal Degradation of Quaternary Ammonium Compounds in Wood," International Research Group on Wood Preservation, Doc. No. IRG/WP98-10263, IRG Secretariat, Stockholm, 1998.

[3] J. J. Morrell, M. E. Corden, B. R. Kropp, P. Przybylowicz, S. M. Smith and C. M. Sexton, "Basidiomycete Colonization of Air Seasoned Douglas-Fir Poles," In: Proceedings of American Wood Preserve Association, Vol. 83, 1987, pp. 284-296.

[4] E. Allen, "Solid Wood Packing Material as a Pathway for Non-Indigenous Species," Online Workshop on Exotic Pests, 2011. http://exoticpests.apsnet.org

[5] R. W. Haack, J. F. Cavey, E. R. Hocbeke and K. Law, "Anoplophora glabripennis: A New Tree-Infesting Exotic Cerambycid Invades New York," Newsletter of the Michigan Entomological Societ, Vol. 41, 1996, pp. 1-3.

[6] J. E. Cavey, E. R. Hoebeke, S. Passon and S. W. Lingafelter, "A New Exotic Threat to North America Harwood Forests: An Asian Longhorned Beetle, Anoplophora Glabripennis (Motschhulsky) (Coleoptera: Cerambycidae), I. Larval Description and Diagnosis," Proceedings of the Entomological Society of Washington, Vol. 100, 1998, pp. 373-381.

[7] I. D. Dwinell, "Heat Treatment and Drying Southern Yellow Pine Lumber Infested with Pinewood Nematodes," Forest Products Journal, Vol. 40, No. 11-12, 1990, pp. 53-56.

[8] I. D. Dwinell, "Heat Treatment Southern Yellow Pine Lumber to Eradicate Bursaphalenchus xylophilus," Nematologica, Vol. 36, 1990, pp. 346-347.

[9] MBTOC, "Assessment Report of the Methyl Bromide Techinical Options Committee," UNEP, Nairobi, 2007, p. 486.

[10] IPPC, "International Plant Protection Convention, No 15 Guidelines for Regulating Wood Packing Material in International Trade (2002) With Modification to Annex (2006)," IPPC, Rome, 2006, p. 11.

[11] IPPC, "IPPC, Recommendation, Replacement or Reduction of the Use of Methyl Bromide as a Phtosantiary Measure," Appendix 6, Report of the third session of the Commission on Phytosanitary Measures, IPPC, Rome, 2008, p. 10.

[12] IPPC, "International Standards for Phtosantiray Measures, Revision of ISPM No. 15," Regulation of Wood Packing Material in Intenational Trade, 2006. https://www.ippc.int/servlet/.

[13] F. Kawakami, Y. Soma, H. Komatsu and Y. Matsumoto, "Effects of Some Fumigants on the Pine Wood Nematode, Bursaphelenchus xylophilus Infesting Wooden Packages. 4. Mortalility and CT Product in Methyl Bromide Fumigation with High Loading of Wood Packing Materials," Res. Bull. Pl. Prot. Japan, Vol. 40, 2004, pp. 7-12.
[14] A. V. Barack, Y. Wang, L. Xu, Z. Rong, X. Hang and G. Zhan, "Methyl Bromide as a Quarantine Treatment for Anoplophora glabripennis (Coleoptera: Cerambycidae) in Regulated Wood Packing Material," Journal of Economic Entomology, Vol. 98, No. 6, 2005, pp. 1911-1916. doi:10.1603/0022-0493-98.6.1911

[15] K. M. Tubajika and A. V. Barak, "Methyl Iodide and Sulfuryl Fluoride as Quarantine Treatments for Solid Wood Packing Material," MBAO Conference, Orlando, 5 November 2007, pp. 131-1-7.

[16] K. M. Tubajika and A. V. Barak, "Efficacy of Sulfuryl Fluoride and Methyl Bromide against Wood-Inhabiting Fungi," In: Proceedings Annual Research Conference on Methyl Bromide Alternatives and Emission, Orlando, 6-9 November 2006, pp. 147-1-8.

[17] USEPA, "Protection of Stratospheric Ozone: Process for Exemption Quarantine and Pre-Shipment Applications of Methyl Bromide," Rules and Regulations, Federal Register, United States Environmental Protection Agency, Vol. 66, No. 139, 2001, pp. 37752-37769.

[18] EPA, 2006. http://www.epa.gov/ozone/mbr.

[19] R. P. Woodward and R. L. Schmidt, "Fungitoxicity of Sulfuryl Fluoride to Ceratocystis fagacearum in Vitro and in Wilted Red Oak Log Sections," Plant Disease, Vol. 79, No. 12, 1995, pp. 1237-1239. doi:10.1094/PD-79-1237

[20] E. E. Kanega, "Some Biological, Chemical, and Physical Properties of Sulfuryl Fluoride as Insecticidal Fumigant," Journal of Economic Entomology, Vol. 50, No. 1, 1957, pp. 1-6.

[21] R. L. Schmidt, T. L. Ambergey, M. L. Sanders and C. D. Bell, "Sulfuryl Fluoride and Methyl Bromide Fumigation of Hardwood Logs of Various Ages for Control of Lumber Graystain," Forest Products Journal, Vol. 48, No. 11/12, 1998, pp. 77-80

[22] W. L. MacDonald, R. L. Schmidt and E. J. Harmer, "Methyl Bromide Eradication of the Oak Wilt Fungus from Red and White Oak Logs," Forest Products Journal, Vol. 35, No. 7-8, 1985, pp. 11-16.

[23] H. L. Barnett, "Isolation and Identification of the Oak Wilt Fungus," West Virginia Experiment Station Bulletin, Vol. 359, 1953, pp. 1-15.

[24] T. W. Jones, "Fumigation May End Oak Embargoes," Forest Products Journal, Vol. 13, No. 12, 1963, p. 564.

[25] A. D Partridge, "Fumigants Kill the Oak Wilt Fungus in Wood," Forest Products Journal, Vol. 11, No. 1, 1961, pp. 12-14.

[26] R. L. Schmidt, "Methyl Bromide Eradication of Oak Wilt Fungus from Lumber," The International Journal of Wood Preservation, Vol. 2, No. 3, 1983, pp. 123-126.

[27] E. L. Schmidt, M. Ruetze and D. W. French, "Methyl Bromide Treatment of Oak Wilt Infected Logs: Laboratory and Preliminary Field Fumigations," Forest Products Journal, Vol. 32, No. 3, 1982, pp. 46-49.

[28] APHIS, "Treatment Manual. Schedule T-312, Oak Logs 
and Lumber," United States Department of Agriculture (USDA), Animal and Plant Health Inspection Service (APHIS), Frederic, 2011, pp. 5-4-26.

http://www.aphis.usda.gov/import_export/plants/manuals/ online_manuals.shtml

[29] R. G. Rhatigan, J. J. Morrell and G. M. Filip, "Toxicity of Methyl Bromide to Four Pathogenic Fungi in Larch Heartwood," Forest Products Journal, Vol. 48, No. 3, 1998, pp. 63-67.

[30] R. L. Schmidt, D. L. Cassens and J. J. Steen, "Log Fumigation Prevents Sticker Stain and Enzyme-Mediated Sapwood Discolorations in Maple and Hickory Lumber," Forest Products Journal, Vol. 47, No. 9, 1997, pp. 47-50.

[31] W. R. Mikle, D. Stewart and O. A. Globus, "Drywood Termite Metabolism of Vikane Fumigant as Shown by
Labeled Pool Technique," Journal of Agriculture and Food Chemistry, Vol. 11, 1963, pp. 226-230. doi:10.1021/jf60127a022

[32] R. H. Scheffrahn, N. Y. Su and R. C. Hsu, "Diffusion of Methyl Bromide and Sulfuryl Fluoride through Selected Structural Wood Matrices during Fumigation," Material and Organismen, Vol. 27, 1992, pp. 147-155.

[33] D. J. Cross, "Penetration of Methyl Bromide into Pinus Radiate Wood and Its Significance for Export Quarantine," New Zealand Journal of Forestry Science, Vol. 21, No. 2-3, 1991, pp. 235-245.

[34] V. Liese, K. Knigge and M. Ruetze, "Fumigation Experiments with Methyl Bromide on Oak Wood," Material and Organismen, Vol. 16, 1981, pp. 265-280. 